\title{
Effect of organic fertilizer and foliar spray with some safety compounds on growth and productivity of snap bean
}

\author{
F. A. Abo-Sedera ${ }^{1}$, A. S. Shams ${ }^{1}$, M. H.M. Mohamed ${ }^{1}$, A. H.M. Hamoda ${ }^{2}$ \\ 1- Horticulture Department, Faculty of Agriculture,Benha University, Egypt. \\ 2- Agriculture Directorate, Qalubia, Benha, Egypt. \\ Corresponding Author: fathy.abosedaira@fagr.bu.edu.eg
}

\begin{abstract}
A field experiment was carried out during the two successive fall seasons of 2014 and 2015 in a private farm at DamaloVillage, QalubiaGovernorate in clay soil, to investigate the effect of three nitrogen sources and foliar spray with some safety compound i.e., compost tea, seaweed extract (Algreen), micronized calcium carbonate (Lithovit) and distilled water (Control) on growth, chemical composition and productivity of snap bean (Phaseolus vulgaris L.) cv. River Grow. This experiments included 12 treatments resulted from the interaction between four foliar applications with safety compound treatments and three nitrogen sources (Chicken manure, Rabbit manure and mineral fertilizer) used at recommended dose of nitrogen (60 kg N/fed.). Obtained results showed that, Rabbit manure at $2.6 \mathrm{t} / \mathrm{fed}$. reflected the highest values of early and total yield in both seasons. In this respect, safety compounds-sprayed plants showed its superiority in the vegetative growth, total produced green pods yield and its components as well as pod quality as compared with the control (distilled water). In addition, using Lithovit at $3 \mathrm{~g} / 1$ followed by Algreenat $2 \mathrm{~cm}^{3} / \mathrm{lcombined}$ with rabbit manure or mineral fertilizer as soil addition reflected the highest values in all studied growth and yield traits.

Thereby, it could be recommended that foliar application with micronized calcium carbonate (Lithovit) as safety compound with mineral fertilizeror rabbit manure (as asource of nitrogen) could be used to improve growth, chemical composition, productivity and quality of snap bean.
\end{abstract}

Key words: Snap bean, compost tea, seaweed extract (Algreen), micronized calcium carbonate (Lithovit), Chicken manure, Rabbit manure and mineral fertilizer, Vegetative growth, yield, pod quality.

\section{Introduction}

Snap bean (Phaseolus vulgarisL.) is one of the most important economic member of legumesin Egypt. It's grown for local consumption and export as an out of vegetable season to European countries. It does not consume large amounts of fertilizer, plus it is consider short season crop, whereas it produce green pod yield through short period after two months from sowing, as well as, it consider as one of the crops that cause soil fertility or neither consumes nor depletes soil nutrients. Moreover, snap bean also plays an important role for human nutrient as good source of protein and carbohydrate. The total area devoted to snap beans during growth season of 2014 was 59687 fed, this area produced 253110 ton with an average yield of 4.24 ton/fed. According to the statistics of Ministry of Agriculture 2014.

As a result of the growing concerns about the adverse effect of chemicals on the environment, agricultural practices involving organic and environmental-friendly compounds are gaining acceptance globally. So, environmental friendly approach of producing high quality organic fertilizer is one of the major concerns of Egyptian researchers. Nutrient balance is the key component to increase crop yields. Excess and imbalanced use of nutrients has caused nutrient mining from the soil, deteriorated crop productivity and ultimately soil health. Replenishment of these nutrients through organics and in combination with organics and inorganics has a direct impact on soil health and crop productivity. In commercial agriculture, the use of chemical fertilizers cannot be ruled out completely. However, there is a need for integrated application for alternate sources for nutrient for sustaining the desired crop productivity (Tiwari, 2002). It has been revealed from the studies on long-term fertilizer experiments that farmyard manure along with chemical fertilizers resulted in yield improvement and maintenance of soil fertility (Swarup, 1998). Integrated farming system is an agricultural system conceived so as to have least impact.Using organic fertilizers; can serve as an alternative practice to use $\mathrm{N}$ mineral fertilizers (Naeemet al., 2006), which play an important role in improving soil physical properties (Daudaet al.,2008). It contributes in increasing the organic soil carbon content and raising soil productivity, through an increase in activity of the useful microorganisms in the soil (El-Gizy,1994)Convert organic nutrient's forms to mineral forms, which become available to plants as the slow-release fertilizers (Marschner, 1995). Moreover, chicken manure contains higher levels of relatively available nutritional elements, especially $\mathrm{N}$, which is essentially required for plant growth (Amanullahet al., 2007).

Seaweed extract application for different crops has a great importance due to its content with high levels of organic matter, micro elements ( $\mathrm{Fe}, \mathrm{Cu}, \mathrm{Zn}$, $\mathrm{Co}, \mathrm{Mo}, \mathrm{Mn}$ and $\mathrm{Ni}$ ), vitamins and amino acids and 
also, it being rich in growth regulators such as auxins, cytokinins and gibberellins (Khan et al.,2009). Exogenous application of seaweed extract has already been shown to enhance plant growth, yield and its quality, as well (Abo El-Yazedet al.2012) on snap bean. Biostimulants seaweed extract (SWE) can promote plant growth may be due to: I) - activate root cells at the same time stimulate biosynthesis of endogenous cytokinins from roots.II)- altering hormonal balances and favorcytokininsand auxins production. III)enhancement of antioxidant enzymes (SOD, GR, ASP) for protection against adverse environmental conditions (Schmidt, 2005). IV) - enhancing leaf water status, some plant nutrients uptake, shoot growth and root pull strength (Demiret al., 2004).

Compost tea there is a global impact for organic farming through recycling of organic waste for persistent agriculture as well as a pollution-free environment. For the development of sustainable farming, waste enrichment of interest. Compost tea, in modern terminology is a compost extract, plant extract, liquid manures and compost teas can be further understood in the context of their influences on the rhizosphere and phyllosphere. Also, manure and compost tea production is a brewing process that extracts microorganisms from compost or manure followed by microbial growth and multiplication including beneficial bacteria, fungi and protozoa (Ingham, 2005).Soil application of compost with compost tea gave good effect on all vegetative growth characteristics and leaves chemical constituents of pigments, macro and micro elements, total carbohydrate, $\mathrm{C} / \mathrm{N}$ ratio and fruit yield compared to the control of snap bean (Abo Sederaet al., 2015).

Lithovet compound containing silica (5\%), magnesium carbonate $(4 \%)$ and calcium carbonate (75\%) particles, extremely small, which gives them the ability to enter through the stomata in leaves of plants when foliar spraying this compound.The positive effect of this compound in being contains magnesium, which is the central element in chlorophyll molecule as that silica plays an important role in plants exposed to drought stress, mainly with respect to water relations and photosynthesis (Raven,
2003) and increases the plants resistance to pathogens and pests (Caiet al., 2009). Also, Calcium carbonate $\left(\mathrm{CaCO}_{3}\right)$ decomposes to calcium oxide $(\mathrm{CaO})$ and carbon dioxide $\left(\mathrm{CO}_{2}\right)$ in leaves stomata, and this carbon dioxide increases the intensity of photosynthesis. In this regard, Artyszaket al. (2014) studied the effect of marine calcite (containing calcium carbonate and silicon mainly) foliar fertilization on the sugar beet cultivar Danuśka KWS. Calcium and silicon foliar fertilization resulted in increases of the root yield about $13.1 \%$ to $21.0 \%$ and increase the biological sugar yield about $15.5 \%$ $17.7 \%$ compared with the control treatment.

Also, Byan (2014) found that using Lithovit(a natural intensified $\mathrm{CO}_{2}$ foliar fertilizer) as foliar spray on snap bean plants cv. Poulistaimproved the values of green pod characters as well as the vegetative growth compared with the control (distilled water).

Therefore, this investigation was carried out to study the effect of some organic and chemical fertilizersas a soil addition as well as using some natural safety compounds as foliar application on vegetative growth, chemical composition, yield and its components, as well as pods quality of snap bean plants under the conditions of Qalubia Governorate.

\section{Materials and Methods}

Two field experiments were carried out during the two successive fall seasons of 2014 and 2015 in a private farm atdamalo village,Benha, Qalubia Governorate to elucidate the effect of organic and mineral fertilizer as well as foliar spray of plants with safety compounds i.e., compost tea, seaweed extract (Algreen) and micronized calcium carbonate (Lithovit) and their interaction on vegetative growth, chemical composition of plant foliage, fresh green pods yield and its components as well as pods quality of snap bean (Phaseolus vulgaris L.) cv. River Grow grown under clay soil conditions. Soil samples were taken from $30 \mathrm{~cm}$ soil surface. Soil physical and chemical properties were determined according to Jackson (1973) and Black et al. (1982) and were illustrated at Table 1.

Table 1. Physical and chemical properties of the experimental soil during the two seasons of study.

\begin{tabular}{|c|c|c|c|c|c|c|c|c|c|c|c|}
\hline Season & $\begin{array}{c}\text { Sand } \\
(\%)\end{array}$ & $\begin{array}{l}\text { Silt } \\
(\%)\end{array}$ & $\begin{array}{c}\text { Clay } \\
(\%)\end{array}$ & Texture & pH & $\begin{array}{c}E C \\
\left(\mathrm{dS} \mathbf{~ m}^{-1}\right)\end{array}$ & $\begin{array}{l}\text { O.M } \\
(\%)\end{array}$ & $\begin{array}{c}\mathrm{CaCO}_{3} \\
(\%)\end{array}$ & $\begin{array}{l}\mathbf{N} \\
\%\end{array}$ & $\mathbf{P} \%$ & $\begin{array}{l}\mathrm{K} \\
\%\end{array}$ \\
\hline 2014 & 21.06 & 25.16 & 53.78 & Clay & 8.2 & 1.03 & 1.30 & 1.53 & 0.12 & 0.31 & 0.10 \\
\hline 2015 & 21.25 & 26.21 & 52.54 & Clay & 8.5 & 0.95 & 1.13 & 1.44 & 0.14 & 0.42 & 0.13 \\
\hline
\end{tabular}

The experiment included twelve treatments resulted from the combination of three nitrogen fertilizer sources (Ammonium nitrate, Rabbit manure and Chicken manure were added at the recommended dose i.e., $60 \mathrm{~kg} \mathrm{~N} / \mathrm{fed}$.) and four foliar spray treatments i.e. seaweed extract (Algreen) at 2 $\mathrm{ml} / \mathrm{l}$,,micronized calcium carbonate (Lithovit) at 3 $\mathrm{g} / \mathrm{l}$., compost tea at $150 \mathrm{ml} / \mathrm{l}$. and control treatment (distilled water only). 
Table 2. Physical and chemical properties of the experimental manure during the two seasons.

\begin{tabular}{lccccc}
\hline \multicolumn{1}{c}{ Item/sander } & Unit & \multicolumn{2}{c}{ Rabbit manure } & \multicolumn{2}{c}{ Chicken manure } \\
\hline Moisture content & & $\mathbf{2 0 1 4}$ & $\mathbf{2 0 1 5}$ & $\mathbf{2 0 1 4}$ & $\mathbf{2 0 1 5}$ \\
Bulk density & $\%$ & 7.1 & 7.6 & 10.8 & 11.2 \\
pH(1:2.5) & $\mathrm{Kg} / \mathrm{m}^{3}$ & 254 & 280 & 325 & 355 \\
EC(1:2.5) & & 6.2 & 6.2 & 6.8 & 6.4 \\
Total nitrogen & $\mathrm{dS} / \mathrm{m}$ & 2.1 & 2.4 & 2.1 & 2.8 \\
Total phosphorus & $\%$ & 2.3 & 2.8 & 1.87 & 1.9 \\
Total potassium & $\%$ & 1.14 & 1.31 & 0.95 & 1.05 \\
Organic matter & $\%$ & 2.23 & 2.44 & 1.14 & 1.4 \\
\hline Organic carbon & $\%$ & 41.2 & 42 & 33.3 & 30.3 \\
\hline
\end{tabular}

A split plot design with four replicates was adopted. Nitrogen fertilizer sources were distributed in the main plots, whereas the foliar spray treatments were randomly arranged in the sub plots. Each experimental plot included four ridges with five meters in length and $60 \mathrm{~cm}$ width with an area of 12 $\mathrm{m}^{2}$.Other agricultural practices were carried out as commonly followed in the district. Seeds of cv. River Grow were obtained from Suez Canal Trade \& Agricultural Development.

Seeds were sown on $6^{\text {th }}$ and $12^{\text {th }}$ of September during the first and second season, respectively. Seeds were sown on one side of the ridges in hill 15 $\mathrm{cm}$ apart. Thinning was done after complete seed germination (21 days) and two plants per hill were left. The amounts of organic fertilizers (Rabbit and Chicken) were added to the soil during soil preparation, while the amount of mineral fertilizers were subdivided into three equal doses and added after complete germination, at flowering and at fruit setting stage. Snap bean plants were sprayed three times starting 21 days and every ten days by intervals during the two seasons of study with all tested spray treatments.

\section{Compost tea preparation:}

The stock of compost tea was prepared by soaking 10 $\mathrm{kg}$ of plant mature compostin 100 liter of water plus $100 \mathrm{ml}$ molasses for 7 days in special unit, attached to air pump and the aerator provides continuous flow of air bubbles to extract compost tea until completion of the fermentation process and extract color becomes light Brown (Fayeket al., 2014). The chemical analysis of used growth stimulators was shown in Table 3.

Table 3.Chemical analysis of spray substances.

\begin{tabular}{|c|c|c|c|c|}
\hline \multirow{2}{*}{ Spray substances } & \multicolumn{4}{|c|}{ Chemical analysis } \\
\hline & Oligaskrades & $0.3 \%$ & Alginic acid & $4 \%$ \\
\hline \multirow{5}{*}{$\begin{array}{l}\text { Algreen } \\
\text { (seaweed extract) }\end{array}$} & Manitol & 0.001 & Zytene & $0.003 \%$ \\
\hline & Cytokinins & 0.001 & IAA & $0.002 \%$ \\
\hline & Bentanee & 0.02 & B & $0.5 \%$ \\
\hline & $\mathrm{N}$ & $6 \%$ & Mn & $0.26 \%$ \\
\hline & $\mathrm{P}_{2} \mathrm{O}_{5}$ & $9.6 \%$ & $\mathrm{Mg}$ & $6 \%$ \\
\hline \multirow{5}{*}{$\begin{array}{l}\text { Lithovit } \\
\text { (Micronized } \\
\text { calcium } \\
\text { carbonate) }\end{array}$} & $\mathrm{CaCO}_{3}$ & $75 \%$ & $\mathrm{~K}_{2} \mathrm{O}$ & $0.1 \%$ \\
\hline & $\mathrm{MgCO}_{3}$ & $4 \%$ & $\mathrm{Na}$ & $0.015 \%$ \\
\hline & $\mathrm{Fe}$ & $0.5 \%$ & $\mathrm{P}_{2} \mathrm{O}_{5}$ & $0.015 \%$ \\
\hline & $\mathrm{SiO}_{2}$ & $5 \%$ & $\mathrm{Mn}$ & $0.01 \%$ \\
\hline & Bulk density $\left(\mathrm{kg} / \mathrm{m}^{3}\right)$ & 1021 & $\mathrm{P}_{2} \mathrm{O}_{5}$ & $0.32 \%$ \\
\hline \multirow{3}{*}{ Compost tea } & $\mathrm{pH}$ & 7.21 & $\mathrm{~K}_{2} \mathrm{O}$ & $0.24 \%$ \\
\hline & $\mathrm{EC}(\mathrm{dS} / \mathrm{m})$ & $0.64 \%$ & O.M.(Organic matter) & $0.18 \%$ \\
\hline & $\mathrm{N}$ & $0.53 \%$ & O.C.( Organic carbon) & $0.10 \%$ \\
\hline
\end{tabular}

\section{Data recorded.}

Vegetative growth traits.

At full blooming stage (60 days from sowing) five plants from each experimental plot were taken and the following data were recorded, plant length, number of branches/plant, number of leaves/plant, leaf area/plant, fresh weight/plant and plant dry weight. Fresh samples were taken then dried in an oven at $70 \mathrm{C}^{0}$ for $72 \mathrm{hrs}$. Then the dry weight of plant was calculated.
Chemical constituents of plant foliage.

Total chlorophyll reading of the fifth mature leaf from top was measured at 60 days from seed sowing using Minolta chlorophyll meter SPAD -502 according to Yadava (1986).

Mineral nutrients,total nitrogen, phosphorus and potassium were determined according to Pregl (1945), John (1970) and Brown and Lilleland (1946), respectively.

3 - Green pods yield and its components. 
Green pods were harvested at proper maturity stage in each harvest for plot and the following data were calculated, early yield/fed. (The first harvest), yield of pods/plant and per feddan.

\section{4- Pods quality.}

Representative sample of 10 pods was taken and average pod length, diameter and weight were recorded.

\section{5- Chemical constituents of green pods.}

A representative sample of green pods (10 pods) was taken and oven dried at $70 \mathrm{c}^{0}$ till constant weight and the dry matter was taken to determine the chemical constituents of pods as follows.

Total nitrogen, it was determined according to Pregle (1945) using the micro-kyeldahl apparatus. A factor of 6.25 was used for conversion of total nitrogen to protein percentage, total carbohydrates, it was determined according to Herbert $\boldsymbol{e t}$ al. (1971). Fiber percentage, it was determined as g/100 g dry weight according to the method in A.O. A.C. (1990). 6- Statistical analysis.

All collected data in both season of study were subjected to analysis of variance as factorial experiments in split plot design. Duncan's analysis was used to differentiate means according to Snedecor and Cochran (1991).

\section{Results and Discussion}

Vegetative growth characteristics.

Data presented in Table 4 show that there were differences in most studied morphological parameters of snap bean plants among the used sources of organic (chicken and rabbit) manure and mineral $(\mathrm{N})$ fertilizer. Each of them applied at the recommended dose of mineral fertilizer $(60 \mathrm{~kg} \mathrm{~N})$ as a soil addition such differences did not reach the level of significance in case of plant height in the first season and number of leaves per plant, total dry weight and leaf area per plant during the second one. In addition, using rabbit manure as organic soil amendment at the recommended dose of mineral fertilizer reflected the highest values in all measured vegetative growth aspects of bean plants compared with mineral and chicken manure fertilizer used in this of study. Such increments in growth parameters in case of using rabbit manure in fertilization may be due to its highest content of nutrient elements and organic matter (Table,2) which may be improved both soil fertility and physical soil characteristics.In addition, rabbit manure considered slow release organic fertilizer lasting long period in the soil and positively affect on plant growth. Obtained results are in agreement with those reported by Ismail (2004), Arjumandet al.(2013) in case of organic fertilizer. AndEl-Awadiet al.(2011), Singh et al. (2011) andMousumi et al.(2015) in case of mineral fertilizer.

As for the effect of foliar spray treatments, the same data in Table 4 indicate that spraying snap bean plants with seaweed extract at a rate of $2 \mathrm{ml} / \mathrm{l}$, micronized calcium carbonate at $3 \mathrm{~g} / \mathrm{l}$ and compost tea at $150 \mathrm{ml} / \mathrm{l}$ significantly increased all measured growth aspects expressed as plant height, number of leaves and branches/plant, fresh and dry weight of plant as well as leaf area/plant compared with the control treatment. Obtained results are true during the two seasons of study. In this regard, spraying the plants with seaweed extract and lithovit (calcium carbonate) exhibited the highest values in all measured growth traits without significant differences among them except in case the number of leaves and branches per plant in which using seaweed extract gave the highest values in the first season only. On contract, compost tea and the control treatments reflected the lowest values of all growth aspects without significant differences in most of them. Such enhancing effects of seaweeds and Lithoviton plant growth measurements are connected with the highest content of them from macro- nutrients and growth regulators Table 3 . Which in turn affect positively on growth rate of plants. Obtained results are coincided with those mentioned byHanafyet al. (2010), Abo El-Yazedet al. (2012),Byan(2014), Gaafar (2014), Zewail (2014), Abo Sederaet al. (2015), El- Atabany (2015) and El-Sayedet al. (2015).

With regard to the effect of the interaction between soil addition fertilizers and foliar spray treatments, the same data in Table 4 indicate that fertilizing the plants with rabbit manure at the recommended dose of mineral fertilizer (60 kg N/fed.)Combined with spraying the plants three timesduring the growth season by using either seaweed extract at $2 \mathrm{ml} / 1$ or Lithovitat $3 \mathrm{~g} / \mathrm{l}$ resulted in the highest values in all growth aspects compared with the other interaction treatments. Obtained results are true during both seasons of study.

\section{Chemical composition of plant foliage}

Concerning the effect of fertilization treatments, it's clear from data in Table 5 that fertilizing snap bean plants with either organic manures i.e., rabbit and chicken manures or mineral fertilizer $(\mathrm{N})$ at the recommended dose $(60 \mathrm{~kg} \mathrm{~N} / \mathrm{fed})$ for both organic and mineral fertilizers reflect a different effect on all assayed chemical constituents i.e., chlorophyll reading, total nitrogen, phosphorus and potassium percentage during the two seasons of study. In this regard, the differences in chemical constituents among the tested fertilizer sources reached the level of significant only in case of total nitrogen in the first season and chlorophyll reading in the second one. In addition, using rabbit manure in fertilization of snap bean plants reflected the highest values of chlorophyll reading and total nitrogen in the first season and total nitrogen in the second season. While fertilizing bean plants with mineral fertilizers exhibited the highest values of phosphorus and potassium content in the first season and chlorophyll reading, phosphorus and potassium content in the 
second one. Such increases in determined chemical constituents as a result of using rabbit manure and mineral fertilizers may be attributed to such fertilizers increased the nutrient elements in rizosphere of roots and consequently improved the absorption and accumulation of assayed chemical constituents in plant foliage. In this connection Ismail (2004)andFernandez-Luqueñoet al. (2010) in case of organic fertilizer.Feleafel and El-Araby (2001) in case of mineral fertilizer reported similar results on snap bean.

Concerning the effect of foliar spray treatments, the same data in Table 5indicate that spraying bean plants three times with seaweed extract at $2 \mathrm{ml} / \mathrm{l}$, lithovit at $3 \mathrm{~g} / \mathrm{l}$ and compost tea at $150 \mathrm{ml} / \mathrm{l}$ tended to increase all assayed chemical constituents of plant foliage i.e., chlorophyll reading, total nitrogen, phosphorus and potassium percentage during both seasons of growth. In addition, such increases reached the level of significancy only in case of chlorophyll reading and total nitrogen percentage during both seasons and phosphorus concentration during the first season only. Moreover, spraying the plants with lithovit reflected the highest values in most assayed chemical constituents followed by using sea weed extract and compost tea in descending order. Such increases in chemical constituents as a result of foliar spray with sea weed extract and lithovit may be due to its chemical constituents from macro and micro- nutrients as well as growth regulators especial in case of sea weed extract which affect positively on nutrient absorption and accumulation in plant cells. Obtained results are similar to those reported byAbo El-Yazedet al.(2012), Zewail (2014),El- Atabany (2015), ElSayed et al. (2015) and Mansori et al.(2015) on snap bean.

As for the effect of the interaction, the same data in Table 5 indicate that fertilizing the plants with either rabbit manure or mineral fertilizer combined with spraying the plant by using seaweed extract reflected the highest value of chlorophyll reading and phosphorus percentage during the first season. While, the same treatments of soil addition combined with lithovit exhibited the highest values of chlorophyll reading and potassium percentage during the second seasons. Moreover, no significant difference was found in case of potassium percentage during the first season and total nitrogen and phosphorus during the second one.

\section{Green pods yield and its components.}

Data in Table 6 indicate that there were some differences in total produced green pods yield and its components expressed as pods yield per plant and early yield per feddan among the used fertilizer sources i.e., chicken manure, rabbit manure and mineral fertilizer in the two seasons of study. In this respect, such differences reached the level of significantly only in case of early yield /fed during the two seasons and pods yield/plant during the second one. In this connection, using rabbit manure reflected the highest value in produced early yield in the first season followed by mineral chemical fertilizer and chicken manure in descending order. While using mineral fertilizers produced the highest values of total pod yield /plant and early yield per feddan during the second season followed by using rabbit and chicken manure in descending order. Such increments in pod yield per plant and early yield per faddan as aresult of rabbit manure and mineral fertilizer may be due to the highest macro- element content in rabbit manure (Table 2) and present of macro- element in easily soluble and available form for absorption in case of mineral fertilizer which increased its content in plant foliage which lead to increase plant growth and consequently increased pods produced per plant and early yield/fed. Obtained results are in agreement with those reported byFeleafel and EL-Araby (2001) andMousumi et al.(2015) on snap bean.

As for the effect of spray treatments on total produced pods yield and its components, such data in Table 6.show that spraying snap bean plants three times during the growth seasons with sea weed extract at $2 \mathrm{ml} / \mathrm{l}$, compost tea at $150 \mathrm{ml} / \mathrm{l}$ and lithovit at $3 \mathrm{~g} / \mathrm{l}$ significantly increased total produced pods yield and its components except the pods yield per plant during the first season only. In this connection, using lithovit in spraying bean plants reflected the highest produced total pods yield and its components expressed as plant yield, early yield and total yield per feddan compared with other used spray treatments and the control one. Moreover, spraying bean plant with using seaweed extract or compost tea enhanced the total produced yield and its components without significant differences among them in most cases compared to the control treatment during the two seasons of study. In this regard, the superiority of using lithovit on total produced yield and its components may be attributed to the role of it as a source of calcium and carbonate which reduced inside plant cell to form carbon dioxide which accumulate in cells and increased the rate of photosynthetic assimilation and consequently increased vegetative growth and produced yield. Similar results were reported by Abo El-yaziedet al. (2012), Byan(2014), Gaafar (2014), Zewail (2014), Abo Sederaet al., (2015), El - atabany (2015)and El-Sayedet al. (2015)on snap bean

As for the effect of the interaction between soil addition treatments and foliar spray treatments on total produced green pods yield and its components i.e., pods yield per plant, early and total yield per faddan. Such data in Table 6 reveal that spraying bean plants with lithovitcompined with fertilizing the plants with either rabbit manure or mineral fertilizer during the first season, and the mineral fertilizer in the second season reflected the highest values in total produced green pods yield and its components. 
Table 4. Effect of organic and mineral fertilizers and foliar spray treatments as well as their interactions on vegetative growth parameters of snap bean plants during the two seasons 2014 and 2015 .

\begin{tabular}{|c|c|c|c|c|c|c|c|c|c|c|c|c|c|}
\hline \multicolumn{2}{|c|}{ Treatments } & $\begin{array}{c}\text { Plant } \\
\text { height } \\
\text { (cm) }\end{array}$ & \multirow[t]{2}{*}{$\begin{array}{c}\text { NO. of } \\
\text { leaves/plant }\end{array}$} & $\begin{array}{c}\text { No. of } \\
\text { branches/plant }\end{array}$ & $\begin{array}{c}\text { Total fresh } \\
\text { weight/plant } \\
\text { (g) }\end{array}$ & \multirow[t]{2}{*}{$\begin{array}{c}\text { Total dry } \\
\text { weight/plant } \\
(\mathrm{g}) \\
\end{array}$} & \multirow[t]{2}{*}{$\begin{array}{c}\text { Leaf } \\
\text { area/plant } \\
\left(\mathbf{c m}^{2}\right) \\
\end{array}$} & $\begin{array}{c}\text { Plant } \\
\text { height } \\
(\mathrm{cm})\end{array}$ & \multirow[t]{2}{*}{$\begin{array}{c}\text { NO. of } \\
\text { leaves/plant }\end{array}$} & $\begin{array}{c}\text { No. of } \\
\text { branches/plant }\end{array}$ & \multirow{2}{*}{$\begin{array}{c}\begin{array}{c}\text { Total fresh } \\
\text { weight/plant } \\
\text { (g) }\end{array} \\
15\end{array}$} & \multirow[t]{2}{*}{$\begin{array}{c}\text { Total dry } \\
\text { weight/plant } \\
\text { (g) } \\
\end{array}$} & \multirow[t]{2}{*}{$\begin{array}{c}\text { Leaf } \\
\text { area/plan } \\
\left(\mathrm{cm}^{2}\right) \\
\end{array}$} \\
\hline & & & & 20 & 14 & & & & & 20 & & & \\
\hline \multirow{3}{*}{ تृ் } & $\begin{array}{l}\text { Chicken } \\
\text { manure }\end{array}$ & $49.09 \mathrm{~A}$ & $19.30 \mathrm{~B}$ & $7.74 \quad \mathrm{~B}$ & $113.7 \mathrm{C}$ & $18.6 \mathrm{C}$ & $800.6 \quad \mathrm{C}$ & $49.22 \mathrm{~B}$ & $20.10 \mathrm{~A}$ & $7.72 \mathrm{~B}$ & $121.4 \mathrm{AB}$ & $19.23 \mathrm{~A}$ & $834.0 \mathrm{~A}$ \\
\hline & $\begin{array}{c}\text { Rabbit } \\
\text { manure }\end{array}$ & $53.38 \mathrm{~A}$ & $21.95 \mathrm{~A}$ & $8.47 \mathrm{~A}$ & 143.9 A & $21.2 \mathrm{~A}$ & $996.8 \mathrm{~A}$ & $53.66 \mathrm{~A}$ & $21.61 \mathrm{~A}$ & $8.28 \mathrm{~A}$ & $122.2 \mathrm{~A}$ & $19.94 \mathrm{~A}$ & $901.8 \mathrm{~A}$ \\
\hline & Mineral & $51.53 \mathrm{~A}$ & $18.29 \quad \mathrm{~B}$ & $7.92 \mathrm{AB}$ & $139.3 \mathrm{~B}$ & $20.7 \quad \mathrm{~B}$ & $954.5 \quad \mathrm{~B}$ & $53.18 \mathrm{~A}$ & $20.48 \mathrm{~A}$ & $7.81 \quad \mathrm{~B}$ & $118.2 \mathrm{~B}$ & $19.35 \mathrm{~A}$ & $876.9 \mathrm{~A}$ \\
\hline \multirow{4}{*}{ 产营 } & Seaweed & $52.76 \mathrm{~A}$ & $22.74 \mathrm{~A}$ & $8.59 \mathrm{~A}$ & $142.0 \mathrm{~A}$ & $20.4 \mathrm{AB}$ & $984.7 \mathrm{~A}$ & $52.31 \mathrm{~A}$ & $20.59 \mathrm{~A}$ & $8.28 \mathrm{~A}$ & $123.3 \mathrm{AB}$ & $19.63 \mathrm{~B}$ & $879.4 \mathrm{~A}$ \\
\hline & Compost tea & $51.23 \mathrm{~A}$ & $19.29 \mathrm{~B}$ & $8.08 \mathrm{AB}$ & $124.5 \quad \mathrm{~B}$ & 20.1 B & $902.4 \quad \mathrm{~B}$ & $52.42 \mathrm{~A}$ & $21.09 \mathrm{~A}$ & $7.99 \mathrm{AB}$ & $120.0 \mathrm{~B}$ & $19.06 \mathrm{C}$ & $824.8 \quad$ B \\
\hline & Lithovit & $53.49 \mathrm{~A}$ & $20.02 \mathrm{~B}$ & $7.98 \mathrm{AB}$ & $142.5 \mathrm{~A}$ & $20.9 \mathrm{~A}$ & $949.8 \mathrm{AB}$ & $53.90 \mathrm{~A}$ & $21.32 \mathrm{~A}$ & $7.91 \mathrm{AB}$ & $125.2 \mathrm{~A}$ & $20.26 \mathrm{~A}$ & $901.5 \mathrm{~A}$ \\
\hline & Control & $47.86 \quad \mathrm{~B}$ & $17.33 \quad \mathrm{C}$ & $7.52 \mathrm{~B}$ & $120.2 \mathrm{~B}$ & $19.2 \mathrm{C}$ & $832.3 \quad \mathrm{C}$ & $49.46 \quad \mathrm{~B}$ & $19.92 \mathrm{~A}$ & $\begin{array}{ll}7.58 \quad \mathrm{~B} \\
\end{array}$ & $113.8 \mathrm{C}$ & $19.08 \mathrm{C}$ & $878.0 \mathrm{~A}$ \\
\hline \multirow{7}{*}{ 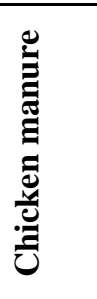 } & Seaweed & 49.10 & 20.87 & & & & 893.2 & 49.53 & & & 123.1 & 19.37 & 832.1 \\
\hline & & $\mathrm{CD}$ & $\mathrm{BCD}$ & $7.97 \mathrm{BC}$ & $121.8 \quad \mathrm{E}$ & $17.5 \quad \mathrm{D}$ & $\mathrm{BCD}$ & $\mathrm{D}$ & $19.73 \mathrm{~A}$ & $8.07 \mathrm{AB}$ & $\mathrm{ABC}$ & $\mathrm{BCD}$ & $\mathrm{CD}$ \\
\hline & Compost tea & $47.30 \quad \mathrm{D}$ & $\begin{array}{l}19.97 \\
\text { CDEF }\end{array}$ & $7.83 \mathrm{BC}$ & 103.0 & $19.4 \mathrm{C}$ & $\begin{array}{l}832.1 \\
\mathrm{DE}\end{array}$ & $\begin{array}{l}49.10 \\
\mathrm{D}\end{array}$ & $20.00 \mathrm{~A}$ & $7.50 \quad \mathrm{~B}$ & $118.3 \mathrm{BC}$ & $18.93 \mathrm{CD}$ & $\begin{array}{l}764.2 \\
\mathrm{D}\end{array}$ \\
\hline & Lithovit & 52.97 & 19.60 & & & & 777.6 & 52.20 & & & & & 852.6 \\
\hline & & $\mathrm{ABC}$ & $\mathrm{CDEF}$ & $7.77 \mathrm{BC}$ & $132.6 \quad \mathrm{D}$ & $20.0 \mathrm{BC}$ & $\mathrm{EF}$ & $\mathrm{ABCD}$ & $21.17 \mathrm{~A}$ & $7.83 \quad \mathrm{~B}$ & $126.4 \mathrm{AB}$ & $20.00 \mathrm{AB}$ & $\mathrm{BC}$ \\
\hline & Control & & 16.77 & & & & 699.6 & 46.07 & & & & & 887.0 \\
\hline & & $47.00 \quad \mathrm{D}$ & $\mathrm{GH}$ & $7.40 \mathrm{C}$ & 97.2 & $17.5 \quad \mathrm{D}$ & $\mathrm{F}$ & $\mathrm{E}$ & $19.50 \mathrm{~A}$ & $7.50 \mathrm{~B}$ & $117.9 \mathrm{BC}$ & $18.60 \quad \mathrm{D}$ & $\mathrm{ABC}$ \\
\hline \multirow{7}{*}{ 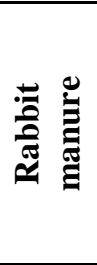 } & Seaweed & & & & & & & & & & & & 913.1 \\
\hline & & $55.40 \mathrm{~A}$ & $25.40 \mathrm{~A}$ & $9.17 \mathrm{~A}$ & $160.7 \mathrm{~A}$ & $22.5 \mathrm{~A}$ & 1115. A & $53.97 \mathrm{AB}$ & $22.53 \mathrm{~A}$ & $8.93 \mathrm{~A}$ & $126.1 \mathrm{AB}$ & $20.27 \mathrm{AB}$ & $\mathrm{AB}$ \\
\hline & Compost tea & 52.53 & 20.27 & & & & 918.8 & & & & 119.3 & & 819.5 \\
\hline & & $\mathrm{ABC}$ & $\mathrm{CDE}$ & $8.63 \mathrm{AB}$ & 134.1 CD & $20.3 \mathrm{BC}$ & $\mathrm{BCD}$ & $54.97 \mathrm{AB}$ & $20.53 \mathrm{~A}$ & $8.30 \mathrm{AB}$ & $\mathrm{ABC}$ & $18.83 \quad \mathrm{D}$ & $\mathrm{CD}$ \\
\hline & Lithovit & $55.07 \mathrm{AB}$ & $23.07 \mathrm{AB}$ & $8.43 \mathrm{ABC}$ & $152.3 \mathrm{AB}$ & $22.2 \mathrm{~A}$ & 1088. A & $55.40 \mathrm{~A}$ & $22.73 \mathrm{~A}$ & $8.07 \mathrm{AB}$ & $127.5 \mathrm{~A}$ & $20.74 \mathrm{~A}$ & $954.7 \mathrm{~A}$ \\
\hline & Control & 50.50 & 19.07 & & 128.7 & & 865.1 & 50.30 & & & & 19.93 & 919.8 \\
\hline & & $\mathrm{BCD}$ & DEFG & $7.63 \mathrm{BC}$ & $\mathrm{DE}$ & $19.7 \mathrm{BC}$ & $\mathrm{CDE}$ & $\mathrm{CD}$ & $20.63 \mathrm{~A}$ & $7.83 \mathrm{~B}$ & $115.7 \mathrm{C}$ & $\mathrm{ABC}$ & $\mathrm{AB}$ \\
\hline \multirow{8}{*}{ 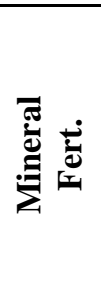 } & Seaweed & 53.77 & & & & & 945.4 & 53.43 & & & 120.8 & 19.27 & 893.0 \\
\hline & & $\mathrm{ABC}$ & $21.97 \mathrm{BC}$ & $8.63 \mathrm{AB}$ & $143.4 \mathrm{BC}$ & $21.0 \mathrm{~B}$ & $\mathrm{BCD}$ & $\mathrm{ABC}$ & $19.50 \mathrm{~A}$ & $7.83 \mathrm{~B}$ & $\mathrm{ABC}$ & $\mathrm{BCD}$ & $\mathrm{ABC}$ \\
\hline & Compost tea & 53.87 & 17.63 & & & & 956.3 & 53.20 & & & 122.4 & 19.40 & 890.6 \\
\hline & & $\mathrm{ABC}$ & EFGH & $7.77 \mathrm{BC}$ & $136.4 \mathrm{CD}$ & 20.7 B & $\mathrm{BC}$ & $\mathrm{ABC}$ & $22.73 \mathrm{~A}$ & $8.17 \mathrm{AB}$ & $\mathrm{ABC}$ & $\mathrm{BCD}$ & $\mathrm{ABC}$ \\
\hline & Lithovit & 52.43 & 17.40 & & & & & & & & 121.7 & & 897.1 \\
\hline & & $\mathrm{ABC}$ & FGH & $7.73 \mathrm{BC}$ & $142.7 \quad \mathrm{C}$ & $20.6 \mathrm{BC}$ & $984.0 \quad \mathrm{~B}$ & $54.10 \mathrm{AB}$ & $20.07 \mathrm{~A}$ & $7.83 \mathrm{~B}$ & $\mathrm{ABC}$ & $20.03 \mathrm{AB}$ & $\mathrm{ABC}$ \\
\hline & Control & & 16.17 & & & & 932.1 & 52.00 & & & & & 827.1 \\
\hline & & $46.07 \quad \mathrm{D}$ & $\mathrm{H}$ & $7.53 \mathrm{BC}$ & $134.7 \mathrm{CD}$ & $20.5 \mathrm{BC}$ & $\mathrm{BCD}$ & $\mathrm{BCD}$ & $19.63 \mathrm{~A}$ & $7.40 \mathrm{~B}$ & 107.7 & 18.70 & $\mathrm{CD}$ \\
\hline
\end{tabular}

Means of the same column followed by the same letter were not significantly different according to Duncan MRT at $5 \%$ 
Table 5. Effect of organic and mineral fertilizers and foliar spray treatments as well as theirinteractions on chemical constituents of plant foliage of snap bean plants during thetwo seasons 2014 and 2015.

\begin{tabular}{|c|c|c|c|c|c|c|c|c|c|}
\hline & \multirow[t]{2}{*}{ Treatments } & $\begin{array}{c}\text { Leaf chlorophyll } \\
\text { reading }\end{array}$ & $\mathrm{N \%}$ & $\mathbf{P} \%$ & \multirow[t]{2}{*}{$\mathbf{K} \%$} & $\begin{array}{c}\text { Leaf chlorophyll } \\
\text { reading }\end{array}$ & $\mathrm{N \%}$ & \multirow[t]{2}{*}{$\mathbf{P \%}$} & \multirow[t]{2}{*}{$\mathrm{K} \%$} \\
\hline & & & & & & & & & \\
\hline \multirow{3}{*}{$\overline{\overline{0}} \frac{\dot{0}}{2}$} & Chicken manure & $40.19 \mathrm{~A}$ & $2.41 \mathrm{~B}$ & $0.592 \mathrm{~A}$ & $1.53 \mathrm{~A}$ & $42.38 \mathrm{AB}$ & $2.60 \mathrm{~A}$ & $0.433 \mathrm{~A}$ & $1.76 \mathrm{~A}$ \\
\hline & Rabbit manure & $44.95 \mathrm{~A}$ & $2.64 \mathrm{~A}$ & $0.567 \mathrm{~A}$ & $1.67 \mathrm{~A}$ & $41.39 \mathrm{~B}$ & $2.62 \mathrm{~A}$ & $0.458 \mathrm{~A}$ & $1.38 \mathrm{~A}$ \\
\hline & mineral & $42.92 \mathrm{~A}$ & $2.51 \mathrm{AB}$ & $0.617 \mathrm{~A}$ & $1.69 \mathrm{~A}$ & $43.54 \mathrm{~A}$ & $2.59 \mathrm{~A}$ & $0.467 \mathrm{~A}$ & $1.82 \mathrm{~A}$ \\
\hline \multirow{4}{*}{ 产 } & Seaweed & $44.66 \mathrm{~A}$ & $2.60 \mathrm{AB}$ & $0.600 \mathrm{AB}$ & $1.60 \mathrm{~A}$ & $43.14 \mathrm{~A}$ & $2.61 \mathrm{AB}$ & $0.422 \mathrm{~A}$ & $1.70 \mathrm{~A}$ \\
\hline & Compost tea & $41.47 \quad \mathrm{~B}$ & $2.67 \mathrm{~A}$ & $0.533 \quad \mathrm{~B}$ & $1.64 \mathrm{~A}$ & $42.13 \mathrm{AB}$ & $2.58 \mathrm{AB}$ & $0.467 \mathrm{~A}$ & $1.48 \mathrm{~A}$ \\
\hline & Lithovit & $44.79 \mathrm{~A}$ & $2.36 \mathrm{C}$ & $0.622 \mathrm{~A}$ & $1.70 \mathrm{~A}$ & $43.88 \mathrm{~A}$ & $2.73 \mathrm{~A}$ & $0.489 \mathrm{~A}$ & $1.79 \mathrm{~A}$ \\
\hline & Control & $39.84 \quad \mathrm{~B}$ & $2.46 \quad B C$ & $0.611 \mathrm{~A}$ & $1.58 \mathrm{~A}$ & $40.59 \quad B$ & $2.49 \quad B$ & $0.433 \mathrm{~A}$ & $1.64 \mathrm{~A}$ \\
\hline \multirow{4}{*}{ 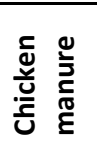 } & Seaweed & $44.03 \mathrm{BCD}$ & $2.67 \mathrm{AB}$ & $0.567 \mathrm{AB}$ & $1.50 \mathrm{~A}$ & $43.60 \mathrm{ABC}$ & $2.57 \mathrm{~A}$ & $0.433 \mathrm{~A}$ & $1.70 \mathrm{ABC}$ \\
\hline & Compost tea & $39.93 \quad \mathrm{DE}$ & $2.37 \quad B C$ & $0.500 \quad \mathrm{~B}$ & $1.53 \mathrm{~A}$ & $41.87 \quad B C$ & $2.67 \mathrm{~A}$ & $0.467 \mathrm{~A}$ & $1.40 \mathrm{ABC}$ \\
\hline & Lithovit & $44.93 \mathrm{ABC}$ & $2.27 \quad \mathrm{C}$ & $0.667 \mathrm{~A}$ & $1.47 \mathrm{~A}$ & $42.40 \quad B C$ & $2.67 \mathrm{~A}$ & $0.433 \mathrm{~A}$ & $2.03 \mathrm{~A}$ \\
\hline & Control & $\begin{array}{ll}31.87 & F \\
\end{array}$ & $2.33 \mathrm{BC}$ & $0.633 \mathrm{AB}$ & $1.63 \mathrm{~A}$ & $41.63 \mathrm{BC}$ & $2.50 \mathrm{~A}$ & $0.400 \mathrm{~A}$ & $1.90 \mathrm{AB}$ \\
\hline \multirow{4}{*}{ 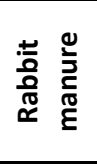 } & Seaweed & $48.67 \mathrm{~A}$ & $2.67 \mathrm{AB}$ & $0.567 \mathrm{AB}$ & $1.63 \mathrm{~A}$ & $42.97 \mathrm{ABC}$ & $2.70 \mathrm{~A}$ & $0.400 \mathrm{~A}$ & $1.47 \mathrm{ABC}$ \\
\hline & Compost tea & $39.00 \quad E$ & $2.97 \mathrm{~A}$ & $0.567 \mathrm{AB}$ & $1.67 \mathrm{~A}$ & $39.87 \quad C$ & $2.47 \mathrm{~A}$ & $0.433 \mathrm{~A}$ & $1.27 \mathrm{C}$ \\
\hline & Lithovit & $46.37 \mathrm{AB}$ & $2.33 \mathrm{BC}$ & $0.600 \mathrm{AB}$ & $1.80 \mathrm{~A}$ & $42.77 \quad B C$ & $2.83 \mathrm{~A}$ & $0.500 \mathrm{~A}$ & $1.37 \mathrm{BC}$ \\
\hline & Control & $45.77 \mathrm{ABC}$ & $2.60 \mathrm{ABC}$ & $0.533 \mathrm{AB}$ & $1.57 \mathrm{~A}$ & $39.97 \quad \mathrm{C}$ & $2.47 \mathrm{~A}$ & $0.500 \mathrm{~A}$ & $1.43 \mathrm{ABC}$ \\
\hline \multirow{4}{*}{ : } & Seaweed & $41.27 \mathrm{CDE}$ & $2.47 \mathrm{BC}$ & $0.667 \mathrm{~A}$ & $1.67 \mathrm{~A}$ & $42.87 \quad \mathrm{BC}$ & $2.57 \mathrm{~A}$ & $0.433 \mathrm{~A}$ & $1.93 \mathrm{AB}$ \\
\hline & Compost tea & $45.47 \mathrm{ABC}$ & $2.67 \mathrm{AB}$ & $0.533 \mathrm{AB}$ & $1.73 \mathrm{~A}$ & $44.67 \mathrm{AB}$ & $2.60 \mathrm{~A}$ & $0.500 \mathrm{~A}$ & $1.77 \mathrm{ABC}$ \\
\hline & Lithovit & 43.07 BCDE & $2.47 \mathrm{BC}$ & $0.600 \mathrm{AB}$ & $1.83 \mathrm{~A}$ & $46.47 \mathrm{~A}$ & $2.70 \mathrm{~A}$ & $0.533 \mathrm{~A}$ & $1.97 \mathrm{AB}$ \\
\hline & Control & 41.90 BCDE & $2.43 \quad B C$ & $0.667 \mathrm{~A}$ & $1.53 \mathrm{~A}$ & $40.17 \quad C$ & $2.50 \mathrm{~A}$ & $0.400 \mathrm{~A}$ & $1.60 \mathrm{ABC}$ \\
\hline
\end{tabular}

Means of the same column followed by the same letter were not significantly different according to Duncan MRT at5\% 
Table 6. Effect of organic and mineral fertilizers and foliar spray treatments as well as their interactions on green pods yield and its components of snap bean plants during the two seasons 2014 and 2015.

\begin{tabular}{|c|c|c|c|c|c|c|c|}
\hline & Treatments & $\begin{array}{c}\text { Pod yields } \\
\text { g/plant }\end{array}$ & Early yield(kg/fed) & Pod yield (ton/fed) & $\begin{array}{l}\text { Pod yields } \\
\text { g/plant }\end{array}$ & Early yield(kg/fed) & Pod yield (ton/fed) \\
\hline & & & 2014 & & & 2015 & \\
\hline \multirow{3}{*}{$\overline{\overline{0}} \frac{0}{\frac{0}{0}}$} & Chicken manure & $349.8 \mathrm{~A}$ & $303.7 \quad B$ & $6.27 \mathrm{~A}$ & $283.3 \quad B$ & $229.2 \quad B$ & $3.81 \mathrm{~A}$ \\
\hline & Rabbit manure & $389.8 \mathrm{~A}$ & $331.0 \mathrm{~A}$ & $6.91 \mathrm{~A}$ & $304.0 \mathrm{AB}$ & $269.9 \mathrm{AB}$ & $4.53 \mathrm{~A}$ \\
\hline & mineral & $385.5 \mathrm{~A}$ & $326.1 \mathrm{AB}$ & $6.94 \mathrm{~A}$ & $318.5 \mathrm{~A}$ & $307.6 \mathrm{~A}$ & $4.52 \mathrm{~A}$ \\
\hline \multirow{4}{*}{ 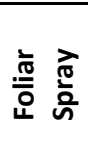 } & Seaweed & $387.6 \mathrm{~A}$ & $306.5 \mathrm{~B}$ & 6.92 B & 298.6 B & $258.7 \quad B$ & $4.43 \mathrm{AB}$ \\
\hline & Compost tea & $358.8 \mathrm{~A}$ & $345.6 \mathrm{~A}$ & $6.20 \mathrm{BC}$ & 295.9 B & $257.4 \quad B$ & $4.19 \mathrm{BC}$ \\
\hline & Lithovit & $397.1 \mathrm{~A}$ & $351.1 \mathrm{~A}$ & $7.92 \mathrm{~A}$ & $318.0 \mathrm{~A}$ & $309.1 \mathrm{~A}$ & $4.71 \mathrm{~A}$ \\
\hline & Control & $356.7 \mathrm{~A}$ & $277.9 \quad \mathrm{C}$ & $5.79 \quad \mathrm{C}$ & $295.3 \quad \mathrm{~B}$ & $250.4 \quad B$ & $3.81 \mathrm{C}$ \\
\hline \multirow{4}{*}{ 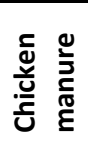 } & Seaweed & $343.0 \quad B$ & $294.3 \quad C$ & $6.33 \mathrm{CD}$ & $286.0 \mathrm{CDE}$ & $265.3 \mathrm{C}$ & $4.13 \mathrm{AB}$ \\
\hline & Compost tea & $364.3 \quad \mathrm{~B}$ & $313.3 \mathrm{C}$ & $6.20 \mathrm{CD}$ & $274.7 \quad E$ & $205.4 \quad \mathrm{D}$ & $3.90 \mathrm{~B}$ \\
\hline & $\begin{array}{l}\text { Lithovit } \\
\end{array}$ & $354.3 \quad \mathrm{~B}$ & $316.1 \quad \mathrm{C}$ & $6.70 \quad B C D$ & 290.7 CDE & $223.9 \mathrm{CD}$ & $4.17 \mathrm{AB}$ \\
\hline & Control & $337.7 \quad \mathrm{~B}$ & $291.1 \quad C$ & $5.87 \quad C D$ & $282.0 \quad \mathrm{DE}$ & $222.3 \mathrm{CD}$ & $3.03 \mathrm{C}$ \\
\hline \multirow{4}{*}{ 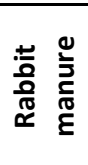 } & Seaweed & $412.3 \mathrm{AB}$ & $314.4 \quad \mathrm{C}$ & $6.87 \mathrm{ABCD}$ & 297.3 BCDE & $248.7 \quad C D$ & $4.57 \mathrm{AB}$ \\
\hline & Compost tea & $332.7 \quad \mathrm{~B}$ & $316.0 \quad \mathrm{C}$ & $6.43 \quad \mathrm{CD}$ & 291.3 CDE & $255.3 \mathrm{C}$ & $4.37 \mathrm{AB}$ \\
\hline & $\begin{array}{l}\text { Lithovit } \\
\end{array}$ & $451.7 \mathrm{~A}$ & $376.6 \mathrm{AB}$ & $8.40 \mathrm{AB}$ & $323.3 \mathrm{AB}$ & $309.7 \quad B$ & $4.97 \mathrm{~A}$ \\
\hline & Control & $362.3 \quad \mathrm{~B}$ & $317.1 \quad \mathrm{C}$ & $5.93 \mathrm{CD}$ & 304.0 BCD & $265.7 \quad C$ & $4.20 \mathrm{AB}$ \\
\hline \multirow{4}{*}{ 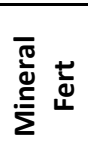 } & Seaweed & $407.3 \mathrm{AB}$ & $310.8 \quad \mathrm{C}$ & $7.57 \mathrm{ABC}$ & $312.3 \quad \mathrm{BC}$ & $262.0 \mathrm{C}$ & $4.60 \mathrm{AB}$ \\
\hline & Compost tea & $379.3 \mathrm{AB}$ & $407.6 \mathrm{~A}$ & $5.97 \quad \mathrm{CD}$ & $321.7 \mathrm{AB}$ & $311.7 \quad$ B & $4.30 \mathrm{AB}$ \\
\hline & Lithovit & $385.3 \mathrm{AB}$ & $360.5 \quad \mathrm{~B}$ & $8.67 \mathrm{~A}$ & $340.0 \mathrm{~A}$ & $393.6 \mathrm{~A}$ & $5.00 \mathrm{~A}$ \\
\hline & Control & $370.0 \quad B$ & $225.5 \quad D$ & $5.57 \quad \mathrm{D}$ & $300.0 \quad B C D E$ & $263.3 \mathrm{C}$ & $4.20 \mathrm{AB}$ \\
\hline
\end{tabular}

Means of the same column followed by the same letter were not significantly different according to Duncan MRT at5\% 
4. Pods quality.

\subsection{Physical quality}

Data in Table 7 indicate that their were differences in all measured physical pod trails of snap bean plants as a result of using different studied sources of fertilizer, i.e. mineral and organic source (chicken and rabbit manure). In this regards, such difference did not reach the level of significant in case of average fresh and dry weight of pods during the two seasons and average pod diameter in the second season only. However, using mineral fertilizer $(\mathrm{N})$ at the recommended dose reflected the highest values of all determined physical pod quality traits in both seasons except average pod length in which using rabbit manure exhibited the highest value in the first season only. Such superiority effect of mineral fertilizer on pod parameters may be due to the presence of mineral elements $(\mathrm{N}, \mathrm{P}, \mathrm{K})$ in available from to absorption by plants which affect on cells division and cells elongation and in turn increased pods parameters. Obtained results are similar to those reported by El- Awadiet al. (2011) and Singh et al.(2011) on snap bean.

As for the effect of growth stimulants on physical pod quality parameters, the same data in Table 8 indicate that spraying snap bean plants with all tested growth stimulants, i.e, seaweed extract at $2 \mathrm{ml} / \mathrm{l}$, compost tea at $150 \mathrm{ml} / \mathrm{l}$ and lithovit at $3 \mathrm{~g} / \mathrm{l}$ tended to increase all measured pod parameters compared to the control treatment during the two seasons of study.In this respect, such increases reached only the level of significant in case of average pod length and pod dry weight during the first season and pod diameter in the second one. In addition, spraying bean plants with either seaweed extract or lithovit exhibited the highest values in all determined pod parameters compared with other tested growth stimulants treatment (compost tea) and the control one during the two seasons of study. Obtained results may be due to the mineral nutrient and growth regulators content of such substances (Table 3) which positively affected on plant growth vigor and inturn increased pods parameters. In this respectByan (2014), Abo Sederaet al. (2015), Elatabany (2015) andEl-Sayedet al. (2015) reported that foliar spray with compost tea,lithovit and seaweed extract improved physical pod quality.

With regard to the effect of the interaction, the same data in Table 7 indicate that average pod length and diameter in the first season and all measured pod traits in second one were significantly affected due to the interaction treatments. In this respect, fertilizing of snap bean plants with rabbit manure and spraying withlithovit gave the highest value of average pod length and diameter during the first and second seasons, respectively. Whereas, fertilizing with using mineral fertilizer combined with spraying with compost tea and lithovit resulted in the highest values of pod diameter in the first season and pod length in case of lithovitand pods dry weight in case of compost tea in the secondseason. However, using rabbitmanure combined with spraying the plants by seaweed extract reflected the highest value in the second season compared with other combination treatments.

\subsection{Chemical pods quality.}

With regard to the effect of fertilization treatments, data in Table 8 show that there were a differences among the fertilization treatments in all measured chemical pods quality expressed as photosynthetic pigments (chlorophyll a, b, total chlorophyll, carotene content), total carbohydrates, protein and fiber percentage during both seasons of study .In this regard, fertilizing snap bean plants with using mineral $(\mathrm{N})$ and rabbit manure at the recommended dose of $\mathrm{N}$ fertilizer gave the highest values in all assayed chemical constituents without significant differences among them except in case of chlorophyll (a) in the first season compared with using chicken manure in the two seasons of study.Such results may be due to the main role of these macro- elements in mineral and rabbit on the structure of chlorophyll molecules and chlorophyll assimilation rate which affect on the assimilation and formation of carbohydrates, protein and fibers. Obtained results are coincided with those reported byIsmail (2004) andMousumiet al.(2015).

Data in Table 8reveal that spraying snap bean plants with different tested growth stimulants (seaweed extract, compost tea, lithovit) increased all measured chemical quality traits compared with the control treatment during the two seasons of study. Such increments reached the level of significance in case of photosynthetic pigments (chlorophyll a, b, total chlorophyll and carotenoids) as well as fiber and protein percentage during the first season and fiber percentage only during the second one. In addition,spraying the plants with lithovit exhibited the highest values in photosynthetic pigments (chlorophyll a, b, total chlorophyll and carotenoids) during the first season and decrease the fiber percentage during both seasons of study compared with other studied treatments. However, spraying bean plants with seaweed extract increased the total protein content during the first season only compared with other treatments. In this respectAbo El-Yazedet al.(2012), Gaafar (2014), Zewail (2014), Abo Sederaet al.(2015) and El- atabany (2015)on snap bean reached to the same results.

As for the effect of the interaction, the same date in Table 8 indicate that all assayed chemical quality traits were significantly affected as a result of all tested interaction treatments except total carbohydrates content during the first season only. In this connection, fertilizing bean plants with rabbit manure combined with spraying the plants by seaweed extract andlithovit reflected the highest values of chlorophyll a, b, total chlorophyll, carotenoids, total carbohydrates and protein content 
during the first season. While, fertilizing the plants with mineral fertilizer combined with compost tea and lithovit as a foliar spray increased all aforementioned parameters of chemical pods quality. However, the lowest fiber percentage was recorded as a result of using rabbit manure as soil addition combined with spraying the plants by seaweed extract and lithovit during the two seasons of growth.

Table7. Effect of organic and mineral fertilizers and foliar spray treatments as well as their interactions on physical fruit quality of snap bean plants during the two seasons 2014and 2015.

\begin{tabular}{|c|c|c|c|c|c|c|c|c|c|}
\hline \multicolumn{2}{|c|}{ Treatments } & $\begin{array}{c}\text { Pod } \\
\text { length }(\mathrm{cm})\end{array}$ & $\begin{array}{c}\text { Pod } \\
\text { diameter(cm) }\end{array}$ & $\begin{array}{c}\text { Pod } \\
\text { length }(\mathrm{cm})\end{array}$ & $\begin{array}{c}\text { Pod } \\
\text { diameter(cm) }\end{array}$ & $\begin{array}{l}\text { Pod fresh } \\
\text { weight(g) }\end{array}$ & $\begin{array}{c}\text { Pod dry } \\
\text { weight(g) }\end{array}$ & $\begin{array}{l}\text { Pod fresh } \\
\text { weight }(\mathrm{g})\end{array}$ & $\begin{array}{c}\text { Pod dry } \\
\text { weight(g) }\end{array}$ \\
\hline & & \multicolumn{4}{|c|}{2014} & \multicolumn{4}{|c|}{2015} \\
\hline \multirow{3}{*}{ ק్̄ } & $\begin{array}{l}\text { Chicken } \\
\text { manure }\end{array}$ & $14.23 \mathrm{C}$ & $0.73 \mathrm{~B}$ & $5.56 \mathrm{~A}$ & $0.57 \mathrm{~A}$ & $14.18 \mathrm{~B}$ & $0.78 \mathrm{~A}$ & $4.80 \mathrm{~A}$ & $0.57 \mathrm{~A}$ \\
\hline & $\begin{array}{l}\text { Rabbit } \\
\text { manure }\end{array}$ & $16.36 \mathrm{~A}$ & $0.76 \mathrm{AB}$ & $6.11 \mathrm{~A}$ & $0.57 \mathrm{~A}$ & $14.27 \mathrm{AB}$ & $0.81 \mathrm{~A}$ & $5.47 \mathrm{~A}$ & $0.58 \mathrm{~A}$ \\
\hline & Mineral & $15.23 \mathrm{~B}$ & $0.81 \mathrm{~A}$ & $6.40 \mathrm{~A}$ & $0.60 \mathrm{~A}$ & $14.82 \mathrm{~A}$ & $0.81 \mathrm{~A}$ & $5.43 \mathrm{~A}$ & $0.56 \mathrm{~A}$ \\
\hline \multirow{4}{*}{ 言 } & Seaweed & $15.67 \mathrm{AB}$ & $0.78 \mathrm{~A}$ & $6.29 \mathrm{~A}$ & $0.61 \mathrm{~A}$ & $14.32 \mathrm{~A}$ & $0.77 \mathrm{C}$ & $5.41 \mathrm{~A}$ & $0.56 \mathrm{~A}$ \\
\hline & Compost tea & $15.22 \mathrm{~B}$ & $0.78 \mathrm{~A}$ & $5.99 \mathrm{~A}$ & $0.58 \mathrm{AB}$ & $14.59 \mathrm{~A}$ & $0.79 \quad \mathrm{BC}$ & $5.31 \mathrm{~A}$ & $0.60 \mathrm{~A}$ \\
\hline & Lithovit & $15.90 \mathrm{~A}$ & $0.74 \mathrm{~A}$ & $6.00 \mathrm{~A}$ & $0.59 \mathrm{AB}$ & $14.52 \mathrm{~A}$ & $0.84 \mathrm{~A}$ & $5.28 \mathrm{~A}$ & $0.57 \mathrm{~A}$ \\
\hline & Control & $14.31 \mathrm{C}$ & $0.77 \mathrm{~A}$ & $5.76 \mathrm{~A}$ & $0.53 \quad \mathrm{~B}$ & $14.27 \mathrm{~A}$ & $0.80 \quad \mathrm{~B}$ & $4.94 \mathrm{~A}$ & $0.56 \mathrm{~A}$ \\
\hline \multirow{4}{*}{ 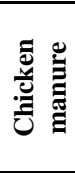 } & Seaweed & $14.33 \quad \mathrm{DE}$ & $0.73 \mathrm{ABC}$ & $5.8 \mathrm{~A}$ & $0.60 \mathrm{~A}$ & $13.83 \mathrm{~B}$ & $0.77 \quad \mathrm{CD}$ & $5.00 \mathrm{AB}$ & $0.57 \mathrm{AB}$ \\
\hline & Compost tea & $14.67 \quad \mathrm{D}$ & $0.73 \mathrm{ABC}$ & $5.47 \mathrm{~A}$ & $0.53 \mathrm{~A}$ & $14.73 \mathrm{AB}$ & $\begin{array}{ll}0.73 & \mathrm{D} \\
\end{array}$ & $4.97 \mathrm{AB}$ & $0.57 \mathrm{AB}$ \\
\hline & Lithovit & $14.43 \quad \mathrm{DE}$ & $0.67 \quad \mathrm{C}$ & $5.57 \mathrm{~A}$ & $0.60 \mathrm{~A}$ & $14.27 \mathrm{AB}$ & $0.83 \mathrm{AB}$ & $4.73 \mathrm{AB}$ & $0.57 \mathrm{AB}$ \\
\hline & Control & 13.50 & $0.77 \mathrm{ABC}$ & $5.37 \mathrm{~A}$ & $0.53 \mathrm{~A}$ & $13.90 \mathrm{~B}$ & $0.80 \mathrm{BC}$ & $4.50 \quad \mathrm{~B}$ & $0.57 \mathrm{AB}$ \\
\hline \multirow{4}{*}{ 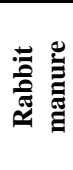 } & Seaweed & $16.17 \mathrm{BC}$ & $0.83 \mathrm{AB}$ & $6.57 \mathrm{~A}$ & $0.57 \mathrm{~A}$ & $14.53 \mathrm{AB}$ & $0.77 \quad \mathrm{CD}$ & $5.77 \mathrm{~A}$ & $0.60 \mathrm{AB}$ \\
\hline & Compost tea & $16.33 \mathrm{BC}$ & $0.73 \mathrm{ABC}$ & $6.03 \mathrm{~A}$ & $0.60 \mathrm{~A}$ & $14.27 \mathrm{AB}$ & $0.80 \quad \mathrm{BC}$ & $5.60 \mathrm{AB}$ & $0.60 \mathrm{AB}$ \\
\hline & Lithovit & $18.00 \mathrm{~A}$ & $0.70 \quad \mathrm{BC}$ & $6.15 \mathrm{~A}$ & $0.57 \mathrm{~A}$ & $14.00 \quad \mathrm{~B}$ & $0.87 \mathrm{~A}$ & $5.43 \mathrm{AB}$ & $0.60 \mathrm{AB}$ \\
\hline & $\begin{array}{l}\text { Control } \\
+ \\
\end{array}$ & 14.93 & $0.80 \mathrm{ABC}$ & $5.67 \mathrm{~A}$ & $0.53 \mathrm{~A}$ & $14.27 \mathrm{AB}$ & $0.80 \mathrm{BC}$ & $5.10 \mathrm{AB}$ & $0.53 \mathrm{AB}$ \\
\hline \multirow{4}{*}{ 预 } & Seaweed & $16.50 \mathrm{~B}$ & $0.77 \mathrm{ABC}$ & $6.47 \mathrm{~A}$ & $0.67 \mathrm{~A}$ & $14.60 \mathrm{AB}$ & $0.77 \quad \mathrm{CD}$ & $5.47 \mathrm{AB}$ & $0.50 \quad \mathrm{~B}$ \\
\hline & Compost tea & 14.67 & $0.87 \mathrm{~A}$ & $6.47 \mathrm{~A}$ & $0.60 \mathrm{~A}$ & $14.77 \mathrm{AB}$ & $0.83 \mathrm{AB}$ & $5.37 \mathrm{AB}$ & $0.63 \mathrm{~A}$ \\
\hline & Lithovit & $15.27 \quad \mathrm{CD}$ & $0.87 \mathrm{~A}$ & $6.43 \mathrm{~A}$ & $0.60 \mathrm{~A}$ & $15.30 \mathrm{~A}$ & $0.83 \mathrm{AB}$ & $5.67 \mathrm{~A}$ & $0.53 \mathrm{AB}$ \\
\hline & Control & $14.50 \mathrm{DE}$ & $0.73 \mathrm{ABC}$ & $6.23 \mathrm{~A}$ & $0.53 \mathrm{~A}$ & $14.63 \mathrm{AB}$ & $0.80 \mathrm{BC}$ & $5.23 \mathrm{AB}$ & $0.57 \mathrm{AB}$ \\
\hline
\end{tabular}

Means of the same column followed by the same letter were not significantly different according to Duncan MRT at5\% 
Table 8. Effect of organic and mineral fertilizers and foliar spray treatments as well as their interactions on chemical fruit quality of snap bean plants during the two seasons 2014 and 2015.

\begin{tabular}{|c|c|c|c|c|c|c|c|c|c|c|c|c|c|c|c|}
\hline \multicolumn{2}{|c|}{ Treatments } & $\begin{array}{c}\text { Chlorophyl } \\
\text { l(a)(mg/100 } \\
\text { g f.w) } \\
\end{array}$ & $\begin{array}{c}\text { Chlorophyl } \\
\text { l(b)(mg/100 } \\
\text { g f.w) }\end{array}$ & $\begin{array}{c}\text { Chlorophyl } \\
\text { l(a+b)(mg/ } \\
\text { 100g f.w) }\end{array}$ & $\begin{array}{c}\text { Carotenoid } \\
\text { s(mg/100g } \\
\text { f.w })\end{array}$ & $\begin{array}{c}\text { Carbohydrates } \\
\%\end{array}$ & $\begin{array}{c}\text { Protein } \\
\%\end{array}$ & $\begin{array}{c}\text { Fiber } \\
\%\end{array}$ & $\begin{array}{c}\text { Chlorophyl } \\
\text { l(a)(mg/100 } \\
\text { g f.w) }\end{array}$ & $\begin{array}{c}\text { Chlorophyl } \\
\text { l(b)(mg/100 } \\
\text { g f.w) }\end{array}$ & $\begin{array}{c}\text { Chlorophyl } \\
\text { l(a+b)(mg/ } \\
\text { 100g f.w) }\end{array}$ & $\begin{array}{c}\text { Carotenoid } \\
\text { s(mg/100g } \\
\text { f.w })\end{array}$ & $\begin{array}{c}\text { Carbohydrates } \\
\%\end{array}$ & $\begin{array}{c}\text { Protein } \\
\%\end{array}$ & $\begin{array}{c}\text { Fiber } \\
\%\end{array}$ \\
\hline & & & & & 2014 & & & & & & & 2015 & & & \\
\hline \multirow{3}{*}{ कृ } & $\begin{array}{l}\text { Chicken } \\
\text { manure }\end{array}$ & $4.17 \quad \mathrm{~B}$ & $2.82 \mathrm{C}$ & $6.99 \quad \mathrm{~B}$ & $3.04 \mathrm{~A}$ & $27.02 \mathrm{~A}$ & $14.86 \mathrm{~A}$ & $9.68 \mathrm{~A}$ & $4.17 \mathrm{~A}$ & $2.77 \mathrm{~A}$ & $6.94 \mathrm{~A}$ & $3.07 \quad \mathrm{~B}$ & $25.67 \quad$ B & $13.84 \quad \mathrm{~B}$ & $9.83 \mathrm{~A}$ \\
\hline & $\begin{array}{l}\text { Rabbit } \\
\text { manure }\end{array}$ & $5.48 \mathrm{~A}$ & $3.99 \quad \mathrm{~B}$ & $9.47 \mathrm{~A}$ & $3.69 \mathrm{~A}$ & $27.18 \mathrm{~A}$ & $15.76 \mathrm{~A}$ & $9.25 \quad$ B & $5.34 \mathrm{~A}$ & $4.25 \mathrm{~A}$ & $9.59 \mathrm{~A}$ & $3.87 \mathrm{~A}$ & $27.66 \mathrm{~A}$ & $16.92 \mathrm{~A}$ & $9.41 \quad \mathrm{~B}$ \\
\hline & mineral & $5.57 \mathrm{~A}$ & $4.31 \mathrm{~A}$ & $9.88 \mathrm{~A}$ & $3.78 \mathrm{~A}$ & $28.34 \mathrm{~A}$ & $15.32 \mathrm{~A}$ & $9.32 \quad \mathrm{~B}$ & $5.69 \mathrm{~A}$ & $4.38 \mathrm{~A}$ & $10.07 \mathrm{~A}$ & $3.79 \mathrm{~A}$ & $27.77 \mathrm{~A}$ & $16.15 \mathrm{~A}$ & $9.32 \mathrm{~B}$ \\
\hline \multirow{4}{*}{ 焉 } & Seaweed & $5.24 \mathrm{AB}$ & $3.37 \mathrm{~B}$ & $8.61 \quad \mathrm{~B}$ & $3.74 \mathrm{~A}$ & $27.78 \mathrm{~A}$ & $16.11 \mathrm{~A}$ & $9.26 \mathrm{~B}$ & $4.51 \mathrm{~A}$ & $3.27 \mathrm{~A}$ & $7.78 \mathrm{~A}$ & $3.44 \mathrm{~A}$ & $26.66 \mathrm{~A}$ & $15.62 \mathrm{~A}$ & $9.63 \mathrm{~A}$ \\
\hline & Compost tea & $4.77 \quad \mathrm{~B}$ & $3.69 \mathrm{AB}$ & $8.46 \quad \mathrm{~B}$ & $3.38 \mathrm{AB}$ & $28.97 \mathrm{~A}$ & $15.51 \mathrm{AB}$ & $9.43 \mathrm{AB}$ & $5.51 \mathrm{~A}$ & $3.83 \mathrm{~A}$ & $9.34 \mathrm{~A}$ & $3.90 \mathrm{~A}$ & $26.70 \mathrm{~A}$ & $15.26 \mathrm{~A}$ & $9.62 \mathrm{~A}$ \\
\hline & Lithovit & $5.97 \mathrm{~A}$ & $4.77 \mathrm{~A}$ & $10.74 \mathrm{~A}$ & $3.78 \mathrm{~A}$ & $26.92 \mathrm{~A}$ & $15.66 \mathrm{AB}$ & $9.27 \quad \mathrm{~B}$ & $5.11 \mathrm{~A}$ & $4.28 \mathrm{~A}$ & $9.39 \mathrm{~A}$ & $3.47 \mathrm{~A}$ & $27.87 \mathrm{~A}$ & $16.44 \mathrm{~A}$ & $9.50 \mathrm{AB}$ \\
\hline & Control & $4.33 \mathrm{~B}$ & $3.01 \mathrm{~B}$ & $7.34 \mathrm{~B}$ & $3.12 \mathrm{~B}$ & $26.40 \mathrm{~A}$ & $13.98 \mathrm{~B}$ & $9.71 \mathrm{~A}$ & $5.07 \mathrm{~A}$ & $3.82 \mathrm{~A}$ & $8.89 \mathrm{~A}$ & $3.50 \mathrm{~A}$ & $26.90 \mathrm{~A}$ & $15.22 \mathrm{~A}$ & $9.32 \mathrm{~B}$ \\
\hline \multirow{4}{*}{ 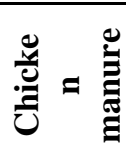 } & Seaweed & 4.27BCD & $1.97 \quad \mathrm{D}$ & $6.24 \quad C D$ & $3.33 \mathrm{ABC}$ & $25.53 \mathrm{~A}$ & $15.97 \mathrm{AB}$ & $9.90 \mathrm{AB}$ & $3.93 \mathrm{BC}$ & $2.53 \mathrm{BC}$ & $6.46 \quad C D$ & $2.97 \mathrm{~B}$ & $24.20 \quad C$ & 14.0CDE & $10.00 \mathrm{AB}$ \\
\hline & Compost tea & $3.73 \quad C D$ & $2.73 \mathrm{BCD}$ & $6.46 \mathrm{BCD}$ & $2.80 \mathrm{BC}$ & $30.43 \mathrm{~A}$ & $14.97 \mathrm{AB}$ & $9.37 \mathrm{BCD}$ & $4.30 \mathrm{BC}$ & $3.47 \mathrm{ABC}$ & 7.77A-D & $2.93 \mathrm{~B}$ & $25.87 \mathrm{BC}$ & 13.57 DE & $10.07 \mathrm{~A}$ \\
\hline & Lithovit & $5.50 \mathrm{ABC}$ & $4.10 \mathrm{~A}-\mathrm{D}$ & $9.60 \mathrm{ABC}$ & $3.57 \mathrm{ABC}$ & $26.70 \mathrm{~A}$ & $14.53 \mathrm{AB}$ & $9.40 \mathrm{BCD}$ & $3.40 \mathrm{C}$ & $2.80 \mathrm{ABC}$ & $6.20 \quad \mathrm{D}$ & $2.93 \mathrm{~B}$ & $27.50 \mathrm{ABC}$ & 14.67B-E & $9.73 \mathrm{ABC}$ \\
\hline & Control & $3.20 \quad \mathrm{D}$ & $2.50 \mathrm{BCD}$ & $5.70 \quad \mathrm{D}$ & $2.47 \quad \mathrm{C}$ & $25.43 \mathrm{~A}$ & $13.97 \mathrm{AB}$ & $10.07 \mathrm{~A}$ & $4.83 \mathrm{ABC}$ & $2.27 \quad \mathrm{C}$ & $7.10 \mathrm{BCD}$ & $3.47 \mathrm{AB}$ & 25.10 BC & $13.07 \quad E$ & $9.53 \mathrm{CDE}$ \\
\hline \multirow{4}{*}{ 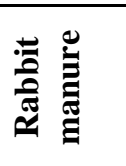 } & Seaweed & $6.00 \mathrm{AB}$ & 4.10A-D & $10.1 \mathrm{ABC}$ & $4.13 \mathrm{~A}$ & $29.10 \mathrm{~A}$ & $17.33 \mathrm{~A}$ & $\begin{array}{ll}8.67 & E \\
\end{array}$ & $4.97 \mathrm{ABC}$ & $4.00 \mathrm{ABC}$ & 8.97A-D & $3.93 \mathrm{AB}$ & $29.63 \mathrm{~A}$ & $16.73 \mathrm{AB}$ & 9.30C-F \\
\hline & Compost tea & 4.90A-D & 3.7ABCD & $8.60 \mathrm{BCD}$ & $3.60 \mathrm{AB}$ & $27.43 \mathrm{~A}$ & $15.43 \mathrm{AB}$ & $9.47 \mathrm{BCD}$ & $5.83 \mathrm{AB}$ & $3.70 \mathrm{ABC}$ & 9.53A-D & $4.20 \mathrm{AB}$ & 25.70 BC & $16.43 \mathrm{ABC}$ & 9.63A-D \\
\hline & Lithovit & $6.63 \mathrm{~A}$ & $5.97 \mathrm{~A}$ & $12.60 \mathrm{~A}$ & $3.87 \mathrm{AB}$ & $26.97 \mathrm{~A}$ & $15.70 \mathrm{AB}$ & $9.40 \mathrm{BCD}$ & $5.53 \mathrm{AB}$ & $4.90 \mathrm{AB}$ & $10.43 \mathrm{ABC}$ & $3.93 \mathrm{AB}$ & $27.73 A B$ & $17.53 \mathrm{~A}$ & $9.27 \mathrm{DEF}$ \\
\hline & Control & $4.40 \mathrm{BCD}$ & $2.20 \mathrm{CD}$ & $6.60 \mathrm{BCD}$ & $3.17 \mathrm{ABC}$ & $25.23 \mathrm{~A}$ & $14.57 \mathrm{AB}$ & $9.47 \mathrm{BCD}$ & $5.03 A B C$ & $4.40 \mathrm{ABC}$ & 9.43A-D & $3.40 \mathrm{AB}$ & $27.57 \mathrm{ABC}$ & $16.97 \mathrm{AB}$ & $9.43 \mathrm{C}-\mathrm{F}$ \\
\hline \multirow{4}{*}{ ن } & Seaweed & 5.47ABC & 4.03A-D & 9.50A-D & $3.77 \mathrm{AB}$ & $28.70 \mathrm{~A}$ & $15.03 \mathrm{AB}$ & $9.20 \mathrm{CDE}$ & $4.63 \mathrm{ABC}$ & $3.27 \mathrm{ABC}$ & 7.90A-D & $3.43 \mathrm{AB}$ & $26.13 A B C$ & 16.07ABC & 9.60B-E \\
\hline & Compost tea & $5.67 \mathrm{AB}$ & $4.63 \mathrm{AB}$ & $10.30 \mathrm{AB}$ & $3.73 \mathrm{AB}$ & $29.03 \mathrm{~A}$ & $16.13 \mathrm{AB}$ & $9.47 \mathrm{BCD}$ & $6.40 \mathrm{~A}$ & $4.33 \mathrm{ABC}$ & $10.73 \mathrm{AB}$ & $4.57 \mathrm{~A}$ & $28.53 \mathrm{AB}$ & 15.77A-D & $9.17 \quad E F$ \\
\hline & Lithovit & $5.77 \mathrm{AB}$ & $4.23 \mathrm{~A}-\mathrm{D}$ & $10.00 \mathrm{ABC}$ & $3.90 \mathrm{AB}$ & $27.10 \mathrm{~A}$ & $16.73 \mathrm{AB}$ & $9.00 \quad \mathrm{DE}$ & $6.40 \mathrm{~A}$ & $5.13 \mathrm{~A}$ & $11.53 \mathrm{~A}$ & $3.53 \mathrm{AB}$ & $28.37 \mathrm{AB}$ & $17.13 \mathrm{~A}$ & 9.50 CDE \\
\hline & Control & $5.40 \mathrm{ABC}$ & $4.33 \mathrm{ABC}$ & $9.730 A B C$ & $3.73 \mathrm{AB}$ & $28.53 \mathrm{~A}$ & $13.40 \mathrm{~B}$ & $9.60 \mathrm{ABC}$ & $5.33 \mathrm{ABC}$ & $4.80 \mathrm{ABC}$ & 10.13A-D & $3.63 \mathrm{AB}$ & $28.03 \mathrm{AB}$ & 15.63A-D & 9.00 \\
\hline
\end{tabular}

Means of the same column followed by the same letter were not significantly different according to Duncan MRT at $5 \%$ 


\section{Reference}

A.O.A.C . 1990. Official Methods of analysis of the Association Official Analytical Chemists. $15^{\text {th }}$ ed. Published by the Association of Official Analytical Chemists, Inc. Anlington, Virginia 22201, U.S.A.

Abo El-Yazed,A.A, A. M. El-Gizawy, M. I.Ragab and E.S.Hamed.2012.Effect of seaweed extract and compost treatments on growth, yield and quality of snap beans. J. of American Sci., 8(6):120.

Abo Sedera, F. A., Nadia. S. Shafshak, A. S. Shams, M. A. Abul-Soud and M. $H$. Mohammed. 2015. The Utilize of Vermicomposting Outputs in Substrate Culture for Producing Snap Bean. Annals Agric. Sci., Moshtohor, 53(2):139-151.

Amanullah, M.M., E. Somasundaram, K. Vaiyapuri and K. Sathyamoorthi.2007. Chicken manure to crops -A Review. Agric. Rev., 28:216-222.

Arjumand, B.S.S, N.B.Ananth and E.T. Puttaiah. 2013. Effectiveness of farm yard manure, poultry manure and fertilizer -NPK on the growth parameters of French bean ((Phaseolus vulgaris L.). In Shimoga, Karnataka.Global j. of Current Research,1(1):31-35.

Artyszak, A., D. Gozdowski and K. Kucińska. 2014. The effect of foliar fertilization with marine calcite in sugar beet, Plant Soil Environ., 60 (9): 413-417

Black, C.A. 1982. Methods of soil analysis.partz. American Society of Agronomy, I N C., publisher, Madison, Wisconsin, USA.

Brown, J. and O. Lilleland. 1946. Rapid determination of potassium and sodium in plant material and soil extracts by flamephotometric. Proc. Amer. Soc. Hort. Sci., 48:341- 346.

Byan, Usrya, A.I. 2014. Influence of using some safety materials on water requirement and water use efficiency of snap bean plant. Arab Univ. J. Agric. Sci., Ain Shams Univ., Cairo, 22(2): 381394.

Cai, K., D.Gao,J. Chen and S.Luo. 2009. Probing the mechanisms of silicon-mediated pathogen resistance. Plant Signaling and Behavior, 4:1-3.

Dauda, S.N., F.A. Ajayi and E. Ndor. 2008. Growth and yield of watermelon (Citrulluslanatus) as affected by poultry manure application. Agric. Soc. Sci., 4:121-124.

Demir, D., A. Günes, A. Inal and M. Alpaslan .2004. Effects of seaweed extract on the yield and mineral nutrition of cucumber (Cucumissativusl.) grown with different salinity levels.IshsActaHorticulturae, 492.Dol.10.17660/ActaHortic.1999.492.

EL-atabany, S.A.M. 2015.Effect of sowing system and foliar spray by safety natural materials on yield and quality of snap bean. Ph.D. Thesis, Fac. Agric., Benha Univ., pp:104.

El-Awadi, M.E., A.M. El-bassiony, Z.F. Fawzyand M.A. Elnemr. 2011. Response of snap bean (Phaseolus vulgaris L.)plants of nitrogen fertilizer and foliar application with methionine and tryptophan. Nature and Science, 9(5):87-94.

El-Gizy, S.M. 1994. Comparative study for influence of manure sources on growth, yield and pod quality of pea. Menofya J. Agric. Res., 19(6):3243-3257.

El-Sayed, Hala A., M. M. Zaghloul, K. A. M.Nour andRasha H. Attia. 2015. Treatment of snap bean plants grown under sandy soil conditions with some natural materials and its relation to growth, yield and pod quality. J. Plant production, Mansoura Univ., 6(3):395-421.

Fayek, M. A., T.A. Fayed, E.M. Fakhrani and N.S. Shaymmaa. 2014. Yield and fruit quality of "Le-conte" pear trees as affected by compost tea and some antioxidants applications. J. Hort. Sci. \& Ornamental plants 6(1):1-8.

Feleafel, M.N. and S.M. El-Aaraby. 2001. Response of snap bean cultivars (Phaseolus vulgaris L.)to varying rates of nitrogen and phosphorus fertilization. J. Agric. Sci. Mansoura Univ., 26(3):1735-1748.

Fernández-Luqueño, F., V. Reyes-Varela, C. Martínez-Suárez, G. SalomónHernández, J. Yáñez-Meneses, J.M. Ceballos-Ramírez and L. Dendooven. 2010. Effect of different nitrogen sources on plant characteristics and yield of common bean (Phaseolus vulgaris L.). Biores. Technol., 101:396-403.

Gaafar, M. S. 2014. Studies on using safety compounds and the application methods on growth and yield of snap bean. Egypt J.Apple.Sci., 29(2):54-81.

Hanafy, A.H., M.R. Nesiem, A.M. Hewedy and H.E. Sallam. 2010. Effect of some stimulative compounds on growth, yield and chemical composition of snap beans plants grown under calcareous soil condition. J. Amer. Sci.,6(10):552-569.

Herbert, D., P.J. Phipps and R.E. Strange.1971.Determination of total carbohydrates, Methods in Microbiology, 5 (8): 290-344.

Ingham, E. 2005. The compost tea brewing manual as printings. Soil Food Web Incorporated, Ovegan,3:31-32.

Ismail, T.B.A. 2004. Effect of drip irrigation rates, organic fertilization and plant density on yield and quality of snap bean. Ph.D. Thesis, Fac. of Agric., Suez Canal Univ., Egypt.

Jackson, M.L. 1973. Soil Chemichal Analysis. Printice-Hall of India.privit Limited, New Delhi.

John, M.K. 1970.Colorimetric determination of phosphorus in soil and plant material with ascorbic acid. Soil Sci., 109: 214-220. 
Khan, W., U.P. Rayirath, S.Subramanian, M.N. Jithesh, P. Rayorath, D.M. Hodges, A.T. Critchley, J.S. Craigie, J.Norrie and B. Prithiviraj.2009. Seaweed extracts as biostimulants of plant growth and development, Plant Growth Regul, 28:386-399.

Mansori, M., H. Chernane, S. Latique, A. Benaliat, D. Hsissou and M. El-Kaoua.2015. Seaweed extract effect on water deficit and antioxidative mechanisms in bean plants (Phaseolus vulgaris L.). J. Applied Phycology, 27(4):1689-1698.

Marschner, H. 1995. "Mineral nutrition of higher plants", $2^{\text {nd }}$ edition. London, UK: Academic press.

Mousumi, S., $P$. $K$.Panda and $P$. Mahapatra.2015. Effect of bio-inoculation and chemical fertilization on growth, yield and quality of French bean (Phaseolus vulgaris L.). Environment and Ecology,33(3):1347-1350.

Naeem, M., J. Iqbal and M.A.A. Bakhsh 2006. Comparative Study of Inorganic Fertilizers and Organic Manures on yield and yield Components of Mungbean (VignaradiatL.), J. Agric. Soc. Sci.,2:227-229.

Pregl, E.1945. Quantitative organic micro analysis. 4th Ed. J. Chundril, London.

Raven, J.A. 2003. Cycling silicon - The role of accumulation in plants. New Phytologist, 158: 419-421.

Schmidt, R.E. 2005.Biostimulants function in turfgrass nutrition. Ph.D. Emeritus Virginia Tech
Singh, B., K.A. Pathak, A.K. Verma, V.K. Verma and B.C. Deka .2011.Effect of vermicompost, fertilizer and mulch on plant growth, nodulation and pod yield of franch bean ((Phaseolus vulgaris L.).Vegetable Crops Research Bulletin, 74:153165.

Snedecor, G. M. and W. G. Cochran. 1991. Statistical methods, Sixth Edition Iowa State Univ. Press, Amer. Iowa, USA.

Swarup, A.1998. Emerging soil fertility management issues for sustainable crop productivity in irrigated systems. In: Swarup A, Reddy Damodar, Prasad RN(Ed). Long term Soil Fertility Management through Integrated Plant Nutrient Supply pp 54-67.Indian Institute of Soil Science, Bhopal, India.

Tiwari, K.N. 2002.Nutrient management for sustainable agriculture. J. Indian Soc. Soil Sci., 50(4):374-397.

Yadava, U. L. 1986. Arpid and non-destructure method to determine chlorophyll in intact leaves. Hort. Sci, 21: 1449-1450.

Zewail, R.M.Y. 2014.Effect of sea weed extract and amino acid on growth and productivity and some bio-constituents of common bean ((Phaseolus vulgaris L.) plants. J. Plant production, Mansoura Univ., 5(8):1441-1453. 


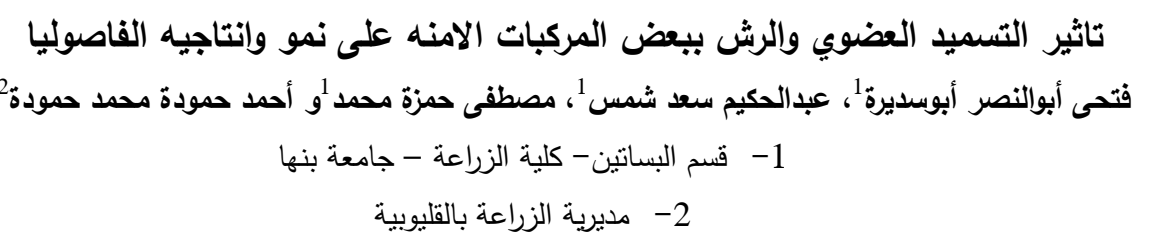

اجريت تجربة حقلية خلال الموسم النيلي لعامي2014 ، 2015م فى مزرعه خاصه بقريه دملو - محافظه القليوبيهلدراسه تأثير الرش بثلاث مركبات امنه ومحفزة للنمو ( شاي الكمبوست بمعدل 150 مل/لتر ،مستخلص الطحالب البحريه "الجرين" بمعدل 2 سم²/لتز ،كربونات الكالسيوم

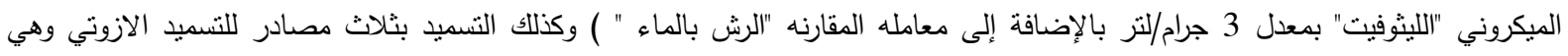

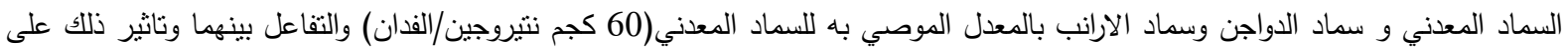
النمو الخضرى والتركيب الكيميائى للمجموع الخضرى للنبات والمحصول الثمرى ومكوناته وكذلك ايضا جودة الثمار الناتجهوقد اشتملت التجربة على 12 معامله تم تصميمها في قطع منشقه حيث تم توزيع المعاملات السماديه الارضيه في القطع الرئيسيه ومعاملات الرش في القطع الفرعيه .

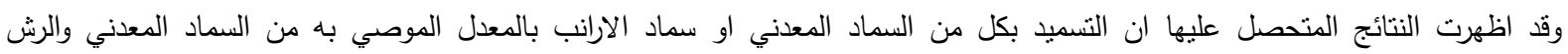

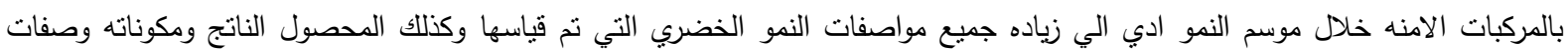

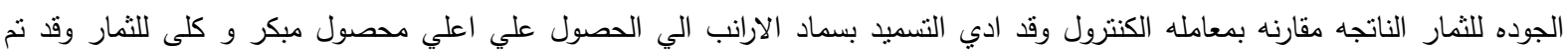
الحصول علي اعلي قيم في هذا الثأن بالرش بكل من كربونات الكاسيوم الميكروني(الليثوفيت) بمعدل 3 جرام/لتز و مستخلص الطحالب البحريه

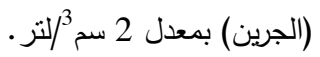
ويمكن بذلك التوصيه بأستخدام السماد المعدني او سماد الارانب اضافه ارضيه بالمعدل الموصي به للسماد المعدني مع الرش بالمركب الأمن

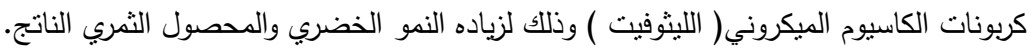
الكلمات الدالة: الفاصوليا الخضراء -شابي الكمبوست - مستخلص الطحالب البحرية- كربونات الكالسبوم الميكروني - سماد دواجن - سماد ارانب- النمو الخضري- المحصول الثمرى- جودة الثمار . 